\title{
Factor VII Activity Measurement
}

National Cancer Institute

\section{Source}

National Cancer Institute. Factor VII Activity Measurement. NCI Thesaurus. Code C103397.

The determination of the amount of the biological activity of factor VII in a sample. 